\title{
ANALISA RESPON INDONESIA TERHADAP MILITERISASI TIONGKOK DI LAUT CHINA SELATAN MASA PEMERINTAHAN PRESIDEN JOKO WIDODO 2014-2019
}

\author{
Anggy Wira Pambudi \\ Paramadina Graduate School Of Diplomacy \\ wiranggy12@gmail.com
}

Doi:

\begin{abstract}
This study discusses how China is trying to assert ownership claims over some areas in the South China Sea by militarizing some areas in the South China Sea. This paper will explain how the threats from the militarization of the South China Sea carried out against the maritime security of Indonesia and how the Government of Indonesia responds to these activities. This study uses a literature study method using the concept of Conventional Detterence and Security Dilemma. This research has found that there is an impact caused by militarization conducted by China in the form of many Chinese ships entering Indonesia illegally and conducting confrontational maneuvers. The Indonesian government responded to this impact by building a military base and supporting facilities aimed only at defending the region without any maneuvering that could trigger an escalation of conflict between the two countries.
\end{abstract}

Keyword: China, South China Sea, Militarization, Indonesia, Natuna

\begin{abstract}
Abstrak
Penelitian ini membahas tentang bagaimana Tiongkok yang sedang berusaha untuk menegaskan klaim kepemilikan terhadap beberapa wilayah di Laut China Selatan dengan melakukan militerisasi beberapa wilayah di Laut China Selatan. Tulisan ini akan menjelaskan bagaimana bentuk ancaman dari Militerisasi Laut China Selatan yang dilakukan oleh terhadap keamanan Maritim Indonesia dan bagaimana Pemerintah Indonesia merespons aktivitas tersebut. Penelitian ini menggunakan metode studi pustaka dengan menggunakan konsep Conventional Detterence dan Security Dilemma. Penelitian ini telah menemukan adanya dampak yang ditimbulkan oleh militerisasi yang dilakukan Tiongkok berupa banyaknya kapal Tiongkok yang masuk ke Indonesia secara ilegal dan melakukan manuver yang konfrontatif. Pemerintah Indonesia merespon dampak ini dengan membangun pangkalan militer beserta fasilitas penunjang yang ditujukan hanya untuk mempertahankan wilayah tanpa adanya manuver yang dapat memicu eskalasi konflik antar kedua negara.
\end{abstract}

\section{Kata kunci: Tiongkok, Laut China Selatan, Militerisasi, Indonesia, Natuna}

\section{Pendahuluan}

Wilayah Laut China Selatan merupakan Laut yang memiliki kompleksitas masalah yang sangat tinggi. Sengketa mengenai kepemilikan Laut China Selatan, melibatkan beberapa negara yang mengklaim kepemilikan wilayah Laut China Selatan seperti Tiongkok, Malaysia, Vietnam, Filipina dan negara dengan status non claimant seperti 
Indonesia, Singapura, Thailand dan Myannmar.

Negara-negara ini memiliki kasus yang berbeda, salah satunya adalah kasus klaim yang dilakukan oleh Tiongkok dengan menggunakan nine dash line sebagai dasar klaim Tiongkok terhadap kepemilikan beberapa wilayah di Laut China Selatan. Garis nine dash line membentang sepanjang $2000 \mathrm{~km}$ dari wilayah China daratan yang melewati dan mencakup beberapa wilayah Filipina, Malaysia dan Vietnam (Joshua, 2005:15).

Dalam menegaskan klaim Tiongkok terhadap kepemilikan beberapa wilayah yang terdapat di Laut China Selatan, Tiongkok hanya menggunakan dasar sejarah pengelolaan Laut China Selatan yang sudah dilakukan oleh masyarakat Tiongkok sejak lama. Pada tahun 1947, Pemerintah Tiongkok melalui Menteri Dalam Negeri mempublikasikan Peta nanhai zhudao weizhitu (Laut China Selatan). Tiongkok juga mengklaim kepemilikan wilayah Pulau Dongsha, Xisha dan Pulau Nansha dengan dasar bahwa Tiongkok merupakan Negara yang pertama kali menemukan, menamakan, menjelajah dan mengeksploitasi kekayaan alam yang terdapat dalam wilayah Pulau tersebut (Shi, 2015:2).

Dalam peta tersebut, pada awalnya memuat 11 garis yang mencakup keseluruhan wilayah Laut China Selatan. Partai komunis Tiongkok menggunakan peta ini sebagai peta resmi dengan pengurangan 2 garis untuk memberikan wilayah teluk Tonkin kepada Partai Komunis Vietnam sebagai persembahan (Tonnesson, 2002: 300).

Pada perkembanganya, garis yang pada awalnya berjumlah 11 dan berkurang menjadi 9 disebut dengan nine dash line. Garis nine dash line yang digunakan dalam peta Tiongkok untuk memuat wilayah Laut China Selatan merupakan sebuah simbol yang menunjukan kedaulatan Tiongkok di wilayah Laut China Selatan dan wujud upaya yang dilakukan oleh warga negara Tiongkok untuk membangun dan mengelola administrasi wilayah Laut China Selatan secara efektif. Nine dash line juga merupakan refleksi dari kepentingan bersama dari masyarakat Tiongkok yang sudah menjadi kesepakatan bersama. (Supriyanto, 2016:21).

Garis nine dash line telah menjadi representasi dari kepentingan bersama Tiongkok yang sudah menjadi kesepakatan bersama, akan tetapi penggunaan nine dash line memicu protes dari negara lain yang menimbulkan sengketa karena garis tersebut dianggap tidak berdasarkan hukum yang berlaku. (Shee, 1998:310)

Klaim kepemilikan wilayah Laut China Selatan yang dilakukan Tiongkok secara sepihak dengan menggunakan dasar prinsip nine dash line telah memicu respons dari negara-negara sekitar termasuk Indonesia yang wilayahnya yaitu wilayah Perairan Natuna termasuk dalam klaim nine dash line Tiongkok. Pemerintah Indonesia melalui Menteri Luar Negeri Retno Marsudi yang menegaskan bahwa klaim Tiongkok tersebut tidak memiliki dasar yang kuat dan menegaskan bahwa wilayah perairan Natuna adalah bagian dari wilayah Indonesia (Michaella, 2016). Akan tetapi, Tiongkok melakukan tindakan lanjutan dari klaim yang telah dilakukan sebelumnya dengan melakukan militerisasi beberapa pulau di wilayah Laut China Selatan seperti wilayah Kepulauan Spratly dan Paracel dengan membangun beberapa instalasi militer Tiongkok di wilayah kedua pulau tersebut (Macias. 2018). 
Tindakan pembangunan beberapa instalasi militer oleh Tiongkok di wilayah yang masih merupakan wilayah sengketa mendapatkan kecaman dari negara negara yang wilayahnya di klaim oleh Tiongkok dan mereka merasa bahwa tindakan yang dilakukan oleh Tiongkok hanya akan memperburuk keadaan karena pada saat itu kasus sengketa ini belum mempunyai keputusan hukum yang memutuskan pemilik sah dari wilayah yang disengketakan.

Pemerintah Tiongkok merespons dengan memberikan keterangan resmi bahwa tindakan militerisasi dengan membangun beberapa instalasi militer yang dilakukan hanya sebagai bentuk upaya mempertahankan wilayahnya dari ancaman (Valencia, 2019). Selain membangun beberapa instalasi militer, Tiongkok juga mengirimkan unit pasukan paramiliternya ke wilayah Laut China Selatan yang berbentuk People Armed Force Maritime Militia (PAFMM).

Penelitian ini akan membahas bagaimana militerisasi beberapa wilayah Laut China Selatan yang dilakukan oleh Tiongkok telah berdampak secara langsung maupun tidak langsung ke negara yang ada di sekitarnya khususnya termasuk negaranegara yang bersengketa tentang kepemilikan wilayah Laut China Selatan termasuk Indonesia. Meskipun posisi Indonesia bukan merupakan negara claimant, tetapi Indonesia juga memiliki kepentingan untuk mempertahankan wilayahnya yaitu wilayah Laut Natuna Utara yang diklaim Tiongkok melalui peta dengan dasar nine dash line.

\section{Metode Penelitian}

Metode penelitian yang digunakan dalam penulisan tulisan ini adalah dengan menggunakan metode pengumpulan data melalui studi pustaka. Sumber yang dapat dijadikan sebagai rujukan adalah berupa buku, jurnal dan artikel ilmiah. Tulisan ini juga menggunakan pendekatan deskriptif analitis untuk menjelaskan sebuah fenomena, kondisi dan situasi yang ada didalam masyarakat dan berupaya untuk menarik fenomena tersebut ke permukaan sebagai suatu ciri, karakter, sifat dengan memusatkan pada suatu unit dari berbagai fenomena yang membutuhkan kedalaman data (Arikunto, 1997:23)

Data yang telah diperoleh kemudian akan melewati proses pengolahan, proses klasifikasi data dan kemudian dibuat sebuah laporan hasil penelitian yang berupa hasil analisa mendalam dari kasus yang sudah melalui proses analisa dan klasifikasi dengan menggunakan konsep dan teori sehingga menghasilkan sebuah kesimpulan yang komprehensif.

\section{Konsep Conventional Detterence}

Conventional Detterence adalah pengembangan dari teori detterence dengan menggunakan persenjataan konvensional sebagai alat utama dalam melakukan ancaman dengan mengkesampingkan penggunaan senjata pemusnah massal sebagai alat dalam melakukan ancaman. John Harvey (1997:7) mengatakan bahwa terdapat beberapa perbedaan dari penggunaan senjata konvensional dengan senjata nuklir seperti kekuatan dan skala dampak penghancuran, cara penggunaan senjata konvensional dan senjata nuklir yang berbeda, tipikal penggunaan senjata dan konsekuensi yang berbeda antara penggunaan senjata konvensional dengan senjata nuklir yang patut menjadi bahan pertimbangan.

Dalam pelaksanaanya, terdapat 2 metode dalam melakukan upaya 
deterrence yaitu deterrence by punishment dan deterrence by denial. Perbedaan dua metode tersebut terletak pada cara pelaksanaanya, deterrence by punishment adalah metode deterrence dengan menggunakan ancaman untuk menyakiti lawan apabila lawan mengambil tindakan yang dianggap mengancam, deterrence by denial adalah metode deterrence dengan kapasitas utntuk mencegah lawan untuk mendapatkan wilayah dan mencapai tujuan mereka (Mitchell, 2015)

Dengan membangun beberapa pangkalan militer beserta fasilitas penunjang di beberapa pulau yang disengketakan, Tiongkok berusaha untuk memberikan tekanan secara tidak langsung kepada negara-negara yang ada disekitarnya khususnya kepada negara-negara yang terlibat dalam kasus sengketa kepemilikan wilayah Laut China Selatan dengan Tiongkok termasuk Indonesia.

\section{Konsep Security Dilemma}

Security Dilemma merupakan teori yang menjelaskan keadaan dimana tindakan yang diambil suatu negara untuk meningkatkan keamananya tetapi menimbulkan reaksi dari negara tetangga yang dapat memicu konflik (Vsevolod, 2011-3).

Dalam implementasinya Security Dilemma merupakan bentuk dari 2 tingkat analisa hubungan antara negara dengan aktor lainya, setiap tingkatan memiliki 2 proposisi yang dapat digunakan oleh para pembuat kebijakan untuk melakukan analisa. Tingkatan awal memuat tentang bagaimana dilema dalam melakukan intrepretasi terhadap motif, tujuan dan kapabilitas dari lawan. Tingkatan kedua memuat tentang dilema dalam melakukan sebuah respons tentang rasionalitas dari respons tersebut (Ziatek, 2017:3).
Tiongkok yang telah menganggap bahwa wilayah Laut China Selatan merupakan masih bagian dari wilayahnya, melihat bahwa upaya militerisasi yang mereka lakukan merupakan upaya mempertahankan diri dari ancaman negara negara yang dianggap mengancam kedaulatan negaranya. Hal ini sejalan dengan pernyataan yang dikemukakan oleh Presiden Tiongkok $\mathrm{Xi}$ Jinping yang menyatakan bahwa ". . . Islands in the South China Sea, since ancient times, are China's territory. We have the right to uphold our own territorial sovereignty and lawful and legitimate maritime rights and interests. . ." (Huaxia, 2015).

Pernyataan Presiden Tiongkok yang menegaskan bahwa upaya pembangunan instalasi militer diwilayah Laut China Selatan sebagai upaya untuk mempertahankan diri dan menjaga kedaulatan mereka. Akan tetapi, instalasi militer yang dibangun Tiongkok diwilayah Laut China Selatan seperti antiship cruise missiles dengan jarak 200 kilometer (ASCMs), longrange surface-to-air missiles (SAM) dengan jarak 300 kilometer dan penempatan radar di beberapa wilayah menunjukan bahwa Tiongkok mencoba untuk mendominasi wilayah Laut China Selatan yang masih dianggap sebagai wilayah negaranya. (Bitzinger, 2016:3)

Pembangunan Instalasi Militer ini menunjukan bagaimana upaya Tiongkok dalam mempertahankan kedaulatan wilayah Laut China Selatan yang masih dianggap sebagai wilayah negaranya. Akan tetapi, pembangunan instalasi militer yang dilakukan secara masif, dengan kemampuan offensive dan dalam wilayah yang masih dalam status sengketa, membuat upaya yang dilakukan Tiongkok mengundang kecaman oleh negara-negara yang masih menganggap bahwa status 
kepemilikan wilayah Laut China Selatan belum menemukan penyelesaian yang pasti.

Teori ini akan digunakan dalam penelitian ini untuk menjelaskan bagaimana Aktivitas militerisasi Tiongkok diwilayah Laut China Selatan diintrepretasi dan direspons oleh negara-negara yang terlibat dalam sengketa kepemilikan wilayah di Laut China Selatan khususnya Indonesia.

\section{Hasil dan Diskusi}

Didalam bagian hasil dan diskusi ini akan membahas bagaimana bentuk upaya militerisasi yang dilakukan oleh Tiongkok di Laut China Selatan dan juga menjelaskan bagaimana Pemerintah Indonesia dibawah Pemerintahan Presiden Joko Widodo merespons aktivitas militerisasi Tiongkok tersebut dengan beberapa tindakan.

\section{Militerisasi Laut China Selatan oleh Tiongkok}

Dalam melakukan militerisasi wilayah Laut China Selatan, pihak Tiongkok memfokuskan pembangunan pangkalan militer beserta fasilitas penunjang di wilayah Pulau Spratly dan Pulau Paracel. Pemilihan wilayah Kepulauan Spratly sebagai salah satu wilayah yang dijadikan tempat militerisasi dengan membangun beberapa fasilitas militer yang dilandasi oleh pertimbangan strategis bagi Tiongkok. Selain membangun pangkalan militer di wilayah Pulau Spratly dan Paracel, Tiongkok juga menempatkan unit paramiliternya di Laut China Selatan yang ditempatkan di pangkalan militer untuk mendukung tugas pengamanan wilayah Laut China Selatan.

\section{Militerisasi Tiongkok di wilayah Kepulauan Spratly}

Militerisasi yang dilakukan oleh Tiongkok di wilayah Kepulauan Spratly memiliki beberapa alasan seperti dasar klaim sejarah yang digunakan Tiongkok sebagai dasar klaim terhadap wilayah Kepulauan Spratly sangatlah lemah. Berdasarkan analisa mendalam terhadap bukti sejarah yang digunakan Tiongkok telah menunjukan bahwa bukti sejarah tersebut tidak berada dalam posisi menguatkan klaim Tiongkok. Sejarah menunjukan bahwa pemerintahan pada zaman tersebut tidak secara resmi mengklaim kedaulatan wilayah Kepulauan Spratly sebagai bagian dari wilayah Tiongkok pada saat itu (Malik, 2013).

Lemahnya dasar sejarah yang digunakan Tiongkok dalam upaya klaim kepemilikan wilayah kepulauan Spratly membuat Tiongkok harus menggunakan cara lain untuk mempertahankan wilayah kepulauan Spratly sebagai dari wilayah Tiongkok. Militerisasi adalah salah satu langkah strategis yang dapat diambil Tiongkok untuk mempertahankan wilayah kepulauan Spratly. Dengan melakukan militerisasi di wilayah kepulauan Spratly akan menunjukan kepada dunia internasional bahwa wilayah tersebut merupakan bagian dari wilayah Tiongkok dan upaya militerisasi Tiongkok di wilayah tersebut merupakan natural right sebuah negara dalam mempertahankan wilayahnya (Patricia, 2018).

Kepulauan Spratly merupakan wilayah yang tersebar dalam wilayah lautan lepas yang luasnya mencapai 158.000 meter persegi dan sejumlah besar wilayah tersebut terendam air. Dari 12 pulau yang terbentuk secara alami, yang terbesar adalah Itu Aba yang memiliki luas 36 hektar (Kenneth, 2015). Di wilayah kepulauan Spratly, Tiongkok melakukan aktivitas militerisasi dengan membangun beberapa instalasi militer di beberapa 
titik seperti Subi Reef dan Mischief Reef.

Dengan melakukan militerisasi di wilayah Kepulauan Spratly akan memberikan dampak positif terhadap upaya mempertahankan argumen klaim kepemilikan Tiongkok terhadap beberapa pulau lainya. Angkatan Laut Tiongkok telah menggunakan isu keamanan Kepulauan Spratly sebagai isu keamanan nasional. Tujuan dari langkah ini adalah untuk meningkatkan kesadaran nasional terhadap isu kemaritiman negara. Langkah ini telah membuat masyarakat Tiongkok mendukung penuh setiap langkah yang diambil oleh Pemerintah Tiongkok terkait Kepualauan Spratly (Taffer, 2015:90).

Masyarakat Tiongkok sangat percaya terhadap media Pemerintah dalam penyebaran informasi. Hal ini dimanfaatkan oleh Pemerintah Tiongkok untuk menjadikan media sebagai alat propaganda untuk mendapatkan dukungan masyarakat khususnya dalam kasus Laut China Selatan. (Zhao, 2015:24).

Dengan tingginya frekuensi pemberitaan isu mengenai sengketa kepemilikan wilayah Kepulauan Spratly akan membuat warga negara Tiongkok sadar akan permasalahan ini. Hal ini akan digunakan Pemerintah Tiongkok untuk menarik simpati masyarakat untuk mendukung langkah yang dilakukan oleh Pemerintah untuk mengamankan wilayah Kepulauan Spratly termasuk upaya militerisasi yang dilakukan oleh Pemerintah Tiongkok. Manfaat dari dukungan masyarakat terhadap upaya militerisasi sebagai salah satu cara yang dilakukan oleh Pemerintah Tiongkok untuk mempertahankan wilayah kepulauan Spratly adalah dengan peningkatan anggaran militer.
Setiap tahunya anggaran pengeluaran militer Tiongkok selalu meningkat 1.1 triliun Yuan pertahun. Peningkatan ini sesuai dengan rencana Presiden $\mathrm{Xi}$ Jinping yang ingin membuat kekuatan sistem pertahanan Tiongkok menjadi kekuatan kelas dunia yang dapat bersaing dan memenangkan perang (Liang, 2018). Dengan peningkatan anggaran ini akan memudahkan Tiongkok untuk melakukan militerisasi di beberapa pulau di wilayah Laut China Selatan yang termasuk didalam klaim kepemilikan yang dilakukan oleh Tiongkok.

\section{Militerisasi Tiongkok di wilayah Kepulauan Paracel}

Kepulauan Paracel adalah kepulauan yang terdiri dari gugusan 130 pulau bebatuan koral dan karang. Kepulauan Paracel membentang 250 mil ke Vietnam dan 220 mil ke pulau Hainan yang merupakan bagian dari wilayah Tiongkok. Pulau pulau yang ada di wilayah kepulauan Paracel merupakan pulau rendah dan tandus yang besarnya tidak melebihi 1 mil persegi (Hansen, 2011: 55).

Pulau Paracel mempunyai peranan penting bagi Tiongkok untuk mempertahankan kepemilikan Laut China Selatan. Dengan membangun sistem pertahanan di wilayah kepulauan Paracel, maka Tiongkok sudah mengamankan "pintu belakang" dari wilayah Laut China Selatan. Sejak tahun 1840 hingga tahun 1949, telah tercatat 479 serangan yang ditujukan kepada Tiongkok melalui laut dan kepulauan Paracel memiliki peran penting dalam mengatasi serangan tersebut (Bouchat, 2014:13).

Kepulauan Paracel juga memiliki peranan penting dalam jalur laut regional. Kepualauan Paracel memiliki letak strategis dalam jalur laut 
khususnya jalur komunikasi dengan wilayah yang berbatasan langsung dengan Laut China Selatan. Selain itu, Kepulauan Paracel juga memiliki peranan penting dalam distribusi kebutuhan energi Tiongkok. Pada faktanya $80 \%$ kebutuhan energi Tiongkok didistribusikan melalui perairan kepulauan Paracel (Stanlas, 2010:4).

Melihat letak strategis yang dimiliki oleh Kepulauan Paracel yang memiliki peranan penting khususnya bagi Tiongkok. Maka tindakan Tiongkok untuk melakukan militerisasi dengan membangun beberapa instalasi dan fasilitas militer di wilayah kepulauan Paracel merupakan langkah yang tepat.

\section{Penempatan PAFMN}

Pasukan militer Tiongkok terdiri dari 3 organisasi, setiap organisasi memiliki subkomponen maritim. Organisasi People Liberation Army (PLA) memiliki PLA NAVY (PLAN), organisasi People Armed Police memiliki Maritime Law Enforcement (MLE) dan organisasi pasukan Militia memiliki pasukan laut berupa People Armed Force Maritime Militia (PAFMM). Setiap pasukan ini memiliki tugas dan fungsi yang berbeda (Yamaguchi. 2016:24)

Pasukan People Armed Force Maritime Militia (PAFMM) beranggotakan masyarakat sipil dan tentara terlatih yang muncul dalam kasus kasus tertentu dan ketika dibutuhkan mereka akan langsung bertindak. Dengan menggunakan kamuflase, kemampuan militer, melepaskan penyamaran, dan mereka menjadi seorang nelayan yang dilindungi oleh hukum (Errickson. 2018). Dalam kasus sengketa Laut China Selatan, PAFMM memiliki peranan yang cukup signifikan bagi upaya Tiongkok dalam mempertahankan wilayahnya. PAFMM yang beroperasi secara rahasia dengan menyamar sebagai nelayan yang dilindungi secara hukum memiliki peranan penting dalam upaya pengamanan wilayah Laut China Selatan.

Dalam operasional PAFMM di Laut China Selatan, PAFMM memiliki pabrik pembuatan kapal penangkap ikan dan apabila dibutuhkan, PAFMM dapat menyewa kapal penangkap ikan dari perusahaan atau kelompok nelayan. PAFMM menggunakan kapal penangkap ikan untuk melakukan aktivitas koersif di Laut China Selatan (Mangosing. 2018). Pada tahun 2016, terdapat insiden dimana terdapat kapal nelayan Tiongkok masuk secara ilegal kedalam wilayah Indonesia dengan alasan bahwa lokasi tersebut merupakan bagian dari wilayah Tiongkok. Pihak TNI AL menduga bahwa kapal tersebut merupakan kapal yang diisi oleh anggota PAFMM (McBeth, 2019).

Peran PAFMM yang sangat signifikan bagi Tiongkok dalam upaya pengamanan Laut China Selatan akan berdampak signifikan bagi Negara yang juga mengklaim kepemilikan wilayah Laut China Selatan. Salah satunya Indonesia, dalam beberapa tahun terakhir telah terjadi beberapa kejadian penangkapan kapal nelayan Tiongkok yang beberapa diantaranya memicu adanya konfrontasi terbuka antara pihak pasukan pengamanan laut Tiongkok dengan pihak otoritas pengamanan laut Indonesia seperti Polisi dan TNI.

Salah satu insiden yang memicu konfrontasi antar pihak otoritas keamanan kedua negara adalah insiden penangkapan kapal Han Tan Chou oleh TNI AL dengan menggunakan KRI Imam Bonjol. Insiden ini bermula Ketika kapal tersebut diamankan dengan pengawalan KRI Imam Bonjol, 
pihak Coast Guard berusaha untuk meminta untuk melepaskan kapal tersebut, akan tetapi permintaan itu ditolak. Pihak Coast Guard tersebut bahkan melakukan manuver provokatif terhadap KRI Imam Bonjol (Gumilang. 2016).

Insiden ini menunjukan bagaimana pihak asing seperti Tiongkok dapat dengan mudah masuk kedalam wilayah perbatasan Indonesia yaitu perairan Natuna Utara dengan menggunakan nelayan yang diduga adalah bentuk penyamaran dari pasukan paramiliter yang termasuk dalam bagian dari PAFMN yang ditempatkan di beberapa pulau di Laut China Selatan yang telah dimiliterisasi.

\section{Rangakaian Latihan Militer TNI di Natuna}

Setelah terjadinya insiden yang melibatkan Kapal Han Tan Cou yang diduga diisi oleh pasukan paramiliter yang didukung oleh pasukan Coast Guard Tiongkok yang melakukan manuver berbahaya terhadap pihak otoritas keamanan laut Indonesia yang pada saat itu sedang melakukan aktivitas pengamanan. Pemerintah Indonesia melalui TNI merespons upaya provokatif tersebut dengan mengadakan latihan militer di perairan Natuna.

Salah satu kegiatan latihan yang dilakukan adalah latihan Angkasa Yudha 2016. Latihan Angkasa Yudha ini pada awalnya akan dilaksanakan di Tanjung Pandan Kabupaten Belitung. Akan tetapi, Presiden Joko Widodo memerintahkan perubahan lokasi latihan menjadi Kepulauan Natuna Provinsi Kepulauan Riau (Suhendra. 2016). Pergeseran tempat latihan menjadi wilayah Kepulauan Natuna sebagai tempat latihan tidak lepas dari serangkaian insiden yang melibatkan kapal Tiongkok dan KRI Imam Bonjol yang terjadi di wilayah perairan Natuna.
Skenario yang diterapkan didalam kegiatan latihan ini adalah skenario pertempuran udara, operasi serangan udara strategis (OSUS), operasi lawan udara ofensif (OLUO), serangan udara langsung (SUL), bantuan tembakan udara (BTU), dan penerjunan logistik berupa cargo delivery system (CDS) maupun heli box (Ziyadi, 2016).

Didalam gelar latihan ini juga melibatkan beberapa alat utama sistem pertahanan (alutsista) seperti Sukhoi Su27/30, F-16, Hawk, T-50i Golden Eagle dan EMB-314 Super Tucano yang diikutsertakan dalam latihan tempur yang disertai oleh penerjunan (Huwa. 2016). Gelar latihan ini juga disaksikan langsung oleh Presiden Joko Widodo yang datang bersama jajaran Menteri untuk meninjau latihan ini (Utama. 2016) Dengan hadirnya Presiden didalam latihan ini telah menunjukan bagaimana latihan ini ditujukan untuk menunjukan kesiapan Indonesia khususnya TNI dalam menghadapi segala bentuk ancaman di wilayah Indonesia khususnya Natuna yang seringkali dimasuki oleh pasukan paramiliter yang menyamar sebagai nelayan yang dikirim dari wilayah Laut China Selatan.

Selain gelar latihan militer Angkasa Yudha, TNI juga mengadakan latihan Pasukan Pemukul Reaksi Cepat (PPRC) di Natuna. Latihan Pasukan Pemukul Reaksi Cepat (PPRC) tahun 2017 akan dilaksanakan di Tanjung Datuk Kepulauan Riau pada 15 Mei 2017. Dalam latihan ini, personel TNI yang dilibatkan berjumlah 5.900 prajurit TNI yang tergabung dalam Satuan Tugas Darat, Satuan Tugas Laut, Satuan Tugas Udara, Satuan Darat, Satuan Manover Infanteri, Satuan Bantuan Tempur, Satuan Bantuan Administrasi (Akbar. 2017). Dalam latihan ini juga melibatkan alat utama sistem senjata (alutsista) antara lain pesawat tempur 
Sukhoi SU-30 dan Sukhoi SU-35, helikopter Super Puma, KRI Yos Sudarso, Tank Leopard, meriam Cesaar dan meriam Giant Bow (Purnomo. 2017).

Skenario dari latihan ini adalah untuk menguji kemampuan prajurit TNI dalam perang taktis dan strategis di tiga matra darat, laut dan udara dalam kondisi darurat tempur dengan tujuan untuk melatih ketangkasan dan kesiapan pasukan jika sewaktu-waktu dibutuhkan bertempur membela NKRI (Ikhsan. 2017). Latihan ini juga dihadiri oleh Presiden Joko Widodo yang datang bersama 23 Gubernur dari seluruh wilayah Indonesia untuk menyaksikan prosesi jalanya latihan ini (Dony. 2017)

Gelar latihan ini merupakan bentuk upaya TNI untuk menunjukan kesiapanya untuk menghadapi segala bentuk ancaman termasuk kemungkinan terjadinya eskalasi konflik yang ada di wilayah Laut China Selatan yang berpotensi akan berpengaruh terhadap keamanan dan stabilitas Indonesia dimana wilayah Natuna termasuk dalam klaim nine dash line Tiongkok. Dengan melibatkan pasukan dari Trimatra yaitu TNI AD, TNI AU, TNI AL. Pihak TNI ingin menunjukan bahwa seluruh komponen TNI dapat terintegrasi dan bekerjasama dalam suatu operasi mengamankan wilayah Indonesia dengan disertai penggunaan Alutsista hasil modernisasi yang telah dilakukan dalam beberapa tahun terakhir.

Melihat besarnya skala gelar latihan ini, pihak TNI harus dapat memastikan bahwa latihan ini hanya berupa "unjuk kesiapan" bukan sebagai upaya "unjuk kebolehan" yang dapat diartikan sebagai upaya provokasi terhadap negara lain khususnya negara yang berbatasan langsung yang dapat memicu adanya konflik terbuka.

\section{Perubahan Nama Laut China Selatan dalam Peta Baru Indonesia}

Pemerintah Indonesia pada tahun 2017 melalui Kementerian Koordinator Bidang Kemaritiman mengeluarkan peta baru dan langsung mendaftarkan peta baru ini ke Perserikatan BangsaBangsa khususnya Organisasi Hidrografik Internasional (Suastha. 2017). Perubahan peta baru ini muncul setelah terjadi beberapa insiden konfrontasi yang melibatkan pihak nelayan dan pihak otoritas keamanan Indonesia di wilayah perairan Natuna yang sempat memicu protes dari kedua negara.

Didalam peta baru ini terdapat perubahan nama Laut China Selatan menjadi Laut Natuna Utara. Perubahan nama Laut China Selatan didalam peta baru yang dikeluarkan oleh Pemerintah Indonesia mendapatkan protes dari pihak Pemerintah Tiongkok. Pemerintah Tiongkok melalui juru bicara Kementerian Luar Negeri Tiongkok Geng Shuang menyatakan bahwa upaya perubahan nama Laut China Selatan yang dilakukan oleh Pemerintah Indonesia sebagai tindakan yang tidak kondusif dan tidak sesuai dengan standar penamaan geografis (Haq. 2017).

Pemerintah Indonesia tidak merespons protes yang dikemukakan oleh Pemerintah Tiongkok. Penamaan wilayah laut merupakan hak dari negara kepulauan yang harus dihormati oleh negara lain. Indonesia telah diakui sebagai negara kepulauan didalam UNCLOS 1982 yang menegaskan hak Indonesia untuk menentukan batas dan menamai wilayah lautnya dan penamaan Laut Natuna Utara dilakukan di wilayah Yurisdiksi laut Indonesia, dan bukan wilayah Laut China Selatan secara keseluruhan (Sinaga. 2017).

Perubahan nama Laut China

Selatan menjadi Laut Natuna Utara 
didalam peta Indonesia yang baru dilakukan untuk mempertegas kedaulatan Indonesia atas wilayah laut di perairan utara Natuna yang akan dapat mencegah pihak-pihak asing seperti pasukan paramiliter yang menyamar menjadi nelayan untuk memasuki wilayah Indonesia secara ilegal dengan menggunakan klaim peta nine dash line yang dibuat oleh Tiongkok untuk melakukan aktivitas melanggar hukum yang dapat memicu konfrontasi dengan pihak keamanan Indonesia.

\section{Pembangunan Pangkalan Militer Indonesia di Natuna}

Meskipun posisi Indonesia didalam kasus sengketa Laut China Selatan bukan merupakan Negara dengan status Claimant akan tetapi terdapat wilayah Indonesia yang masuk didalam klaim Tiongkok yang memasukan wilayah Indonesia yaitu wilayah perairan Laut Natuna Utara. Sikap Tiongkok yang berusaha menegaskan klaim kepemilikan wilayah Laut China Selatan dengan melakukan militerisasi di wilayah Laut China selatan berpotensi menganggu stabilitas wilayah.

Pandangan Pemerintah Indonesia melalui Buku Putih Pertahanan yang diterbitkan pada tahun 2015 melihat upaya militerisasi dan modernisasi yang dilakukan oleh Tiongkok dapat memunculkan situasi dilema keamanan antar negara-negara yang bersengketa. Kondisi dilema keamanan inilah yang memicu negara-negara yang berada disekitar Laut China Selatan untuk mengambil sebuah respons.

Pemerintah Indonesia selama era kepemimpinan Presiden Joko Widodo telah menempatkan isu keamanan di Laut China Selatan sebagai salah satu isu pertahanan strategis sebagaimana tercantum didalam Buku Putih
Pertahanan yang dikeluarkan oleh Kementerian Pertahanan.

Selama era kepemimpinan Presiden Joko Widodo anggaran pertahanan Indonesia mengalami kenaikan yang cukup signifikan dibandingkan anggaran pertahanan di era kepemimpinan Presiden Susilo Bambang Yudhoyono (Daud. 2019). Untuk memperkuat pertahanan Indonesia di wilayah perbatasan, pihak Dewan Perwakilan Rakyat telah menyetujui untuk menganggarkan anggaran untuk membangun pangkalan militer di Natuna untuk mengantisipasi ancaman yang muncul dari Laut China Selatan khususnya Tiongkok (Indrawan, 2015)

Pada tahun 2016, Kementerian Pertahanan mengajukan anggaran untuk tahun 2017 yang akan diprioritaskan untuk membangun pangkalan militer di Natuna dan modernisasi Alutsista yang sudah dianggap tidak layak untuk digunakan (Gumilang, 2016). Karena keterbatasan anggaran yang didapat oleh TNI dan Kementerian Pertahanan, pembangunan pangkalan militer di Natuna akan dilakukan secara bertahap hingga membentuk pangkalan militer secara utuh yang akan digunakan untuk penegakan hukum dalam menyelesaikan persoalan pelanggaran di sekitar Laut China Selatan (Sarwanto, 2016)

Rencana pembangunan pangkalan militer yang digagas oleh Kementerian Pertahanan dan TNI telah menunjukan bagaimana situasi di Laut China Selatan khususnya di wilayah Natuna yang berpotensi mengancam stabilitas keamanan dan kedaulatan Indonesia sehingga mengharuskan Pemerintah Indonesia untuk memberikan respons terhadap ancaman yang ada.

Melihat situasi dan kondisi wilayah Natuna sebagai wilayah terluar yang seringkali menjadi wilayah rawan konflik menjadikan program 
pembangunan pangkalan militer di Natuna menjadi program yang penting untuk dilaksanakan yang dapat digunakan untuk penegakan hukum, penjagaan wilayah dari pihak asing yang berusaha memasuki wilayah Indonesia secara ilegal untuk melakukan tindakan yang melanggar hukum dan sekaligus pembangunan pangkalan militer ini untuk menegaskan bahwa wilayah kepulauan Natuna merupakan wilayah yang sah secara hukum sebagai bagian dari wilayah Negara Kesatuan Republik Indonesia.

\section{Pembentukan Satuan TNI Terintegrasi dan Komando Gabungan Wilayah Pertahanan}

Setelah dibangunya pangkalan militer dan beserta fasilitas penunjang pangkalan militer tersebut maka program Pemerintah selanjutnya adalah membentuk satuan TNI terintegrasi dan Komando Gabungan Wilayah Pertahanan.

Tujuan dibentuknya satuan TNI terintegrasi ini ditujukan untuk memberikan daya tangkal terhadap setiap ancaman di wilayah Natuna. Pembangunan satuan TNI terintegrasi akan berkembang menjadi organisasi permanen dan terintegrasi dalam satu komando dan dilengkapi sistem kendali operasi berbasis network centric warfare (Astungkoro. 2018).

Pada saat ini, Satuan TNI terintegrasi masih dalam tahap embrio awal yang terdiri dari beberapa satuan TNI seperti dari satuan TNI Angkatan Darat, TNI Angkatan Udara dan TNI Angkatan Laut yang terdiri dari: (Nupus. 2018)

1. TNI Angkatan Darat seperti Batalyon Komposit, Kompi Zeni Tempur, Baterai Rudal Artileri Pertahan Udara dan Baterai Artileri Medan.
2. TNI Angkatan Laut dari Kompi Komposit Marinir dan fasilitas pelabuhan untuk mendukung operasional Kapal Perang TNI AL yang beroperasi disekitar perairan Natuna

3. TNI Angkatan Udara berupa pangkalan udara, lengkap dengan fasilitas seperti Hanggar Integratif dan Hanggar Skuadron Unmanned Aerial Vehicle (UAV).

Untuk menunjang operasional Satuan TNI Terintegrasi, telah dibangun beberapa fasilitas penunjang operasional seperti Rumah Sakit, Hanggar Integratif tiga matra TNI, Dermaga fasilitas pelabuhan TNI AL dan fasilitas radar TNI AU (Permana, 2018). Setelah tiga matra TNI telah terintegrasi sepenuhnya, maka tahapan selanjutnya adalah pembangunan Komando Gabungan Wilayah Pertahanan (KOGABWILHAN). Pembentukan KOGABWILHAN sudah direncanakan pada masa Presiden Susilo Bambang Yudhoyono yang diteruskan oleh Presiden Joko Widodo.

Unsur-unsur yang diperhatikan dalam pembentukan KOGABWILHAN antara lain jabatan Panglima, beserta seluruh jajaran stafnya, kemudian menyusul unsur satuan pelaksana. Komando gabungan ini terdiri dari 3 wilayah gabungan yaitu barat, tengah dan timur (Putra. 2015). Dasar dari pembentukan KOGABWILHAN sudah diresmikan dalam bentuk Perpres 62/2016 dengan struktur KOGABWILHAN yang akan dipimpin Perwira Tinggi berpangkat bintang tiga. Dengan Perwira Tinggi berbintang dua sebagai wakil dan enam asisten berpangkat bintang satu (Eksa, 2019)

Pembentukan satuan TNI terintegrasi dan Komando Gabungan Wilayah Pertahanan telah menunjukan bagaimana Pemerintah Indonesia tidak 
hanya memfokuskan upaya untuk menjaga keamanan Laut China Selatan hanya dengan membangun pangkalan militer beserta fasilitas penunjangnya, tetapi juga membentuk struktur yang mengoperasionalkan pangkalan militer tersebut. Dengan pembangunan pangkalan militer dengan disertai satuan TNI yang telah terintegrasi dan Komando Gabungan Wilayah yang sudah dibentuk, kegiatan operasional dari pangkalan militer tersebut akan dapat terkonsolidasi dan terarah dalam satu komando pimpinan.

\section{Kesimpulan}

Kondisi stabilitas Laut China Selatan semakin memburuk setelah Tiongkok melakukan upaya militerisasi di beberapa wilayah yang dianggap sebagai bagian dari negara Tiongkok berdasarkan peta nine dash line yang dirilis oleh Pemerintah Tiongkok. Upaya militerisasi ini telah membuat munculnya potensi eskalasi konflik menjadi konflik terbuka antar negaranegara yang sifatnya sebagai claimant dan non claimant.

Salah satu negara yang dapat merasakan dampak dari militerisasi yang dilakukan Tiongkok di Laut China Selatan adalah Indonesia. Meskipun status Indonesia bukan merupakan negara dengan status claimant, akan tetapi Indonesia memiliki kepentingan dimana salah satu wilayahnya yaitu wilayah perairan Laut Natuna Utara ikut diklaim sebagai bagian dari wilayah negara Tiongkok didalam peta nine dash line yang dibuat oleh Tiongkok.

Militerisasi Laut China Selatan yang dilakukan oleh Tiongkok dengan membangun pangkalan militer beserta fasilitasnya dan penempatan pasukan militer dan paramiliter. Tindakan militerisasi yang dilakukan oleh Tiongkok di Laut China Selatan secara langsung tidak langsung memberikan dampak penekanan dengan menggunakan perangkat konvensional yang mengancam keamanan nasional khususnya keamanan wilayah terluar Indonesia.

Dalam beberapa tahun terakhir, di wilayah perairan Natuna seringkali terdapat insiden yang melibatkan kapal nelayan berbendera Tiongkok dengan pihak otoritas keamanan Laut Indonesia. Kapal nelayan yang berbendera Tiongkok tersebut dicurigai sebagai pasukan paramiliter Tiongkok yang ditempatkan di Laut China Selatan untuk ditugaskan melakukan aktivitas pengawasan di wilayah perbatasan yang disengketakan.

Kapal nelayan tersebut memasuki wilayah negara lain secara ilegal untuk melakukan aktivitas melanggar hukum. Seringkali ketika pihak otoritas keamanan berusaha untuk mengamankan kapal tersebut, kapal tersebut memberikan perlawanan dengan disertai manuver yang bersifat provokatif.

Pemerintah Indonesia dibawah kepemimpinan Presiden Joko Widodo memberikan perhatian khusus kepada potensi konflik yang akan terjadi di Laut China Selatan sebagaimana tertuang didalam Buku Putih Pertahanan Indonesia yang dirilis oleh Kementerian Pertahanan.

Pemerintah Indonesia telah mengambil beberapa respon tindakan untuk merespon ancaman potensi konflik yang ada di Laut China Selatan seperti melakukan beberapa rangkaian gelar latihan militer di wilayah perairan Natuna. Gelar latihan militer ini ditujukan untuk "unjuk kesiapan" dan bukan "unjuk kebolehan". Rangkaian gelar latihan militer ini merupakan bentuk pesan yang coba ditunjukan oleh Pemerintah Indonesia melalui TNI.

$$
\text { Selama ini banyak nelayan }
$$
Tiongkok yang memasuki wilayah 
perairan Natuna dengan bebas karena masih menganggap bahwa wilayah perairan Natuna merupakan bagian dari wilayahnya sebagaimana dimuat didalam peta nine dash line. Dengan adanya rilis peta baru Indonesia dengan adanya perubahan nama wilayah perairan Natuna dapat dijadikan dasar pihak otoritas pengamanan laut Indonesia untuk melakukan pengamanan dan penindakan terhadap nelayan Tiongkok yang memasuki wilayah Indonesia secara ilegal.

Untuk memastikan keamanan wilayah Natuna Pemerintah Indonesia juga melakukan upaya untuk membangun pangkalan militer disertai pembentukan satuan TNI terintegrasi dan juga Komando Gabungan Wilayah. Sebagaimana Tiongkok yang membangun pangkalan militernya di wilayah yang dianggap sebagai bagian dari upaya mempertahankan wilayahnya, pihak Indonesia juga harus membangun kekuatan militernya di wilayah Natuna.

Pembangunan kekuatan militer ini bukan ditujukan untuk berkompetisi, akan tetapi ditujukan sebagai bentuk penegasan bahwa Laut Natuna Utara merupakan bagian dari wilayah Indonesia. Hal ini merupakan bentuk dari Dilemma Keamanan yang diawali oleh Tiongkok yang membangun kekuatan militer atas dasar mempertahankan wilayahnya. Pemerintah Indonesia harus memastikan bahwa pembangunan kekuatan militer ini tidak memicu adanya efek domino berupa persaingan persenjataan antar negara negara yang terlibat yang apabila terjadi dapat memicu eskalasi konflik menuju tahapan konflik terbuka yang akan membuat keadaan menjadi semakin tidak kondusif.

Dari keseluruhan respon yang diambil oleh Pemerintah pada era kepemimpinan Presiden Joko Widodo telah menunjukan bagaimana Pemerintah Indonesia telah memberikan perhatian khusus terhadap isu ini. Pemerintah Indonesia yang menghadapi situasi Dilema Keamanan berusaha memberikan respon yang efektif dan tidak memicu adanya eskalasi konflik menjadi konflik terbuka karena pihak Indonesia berusaha untuk menjaga hubungan baik dengan seluruh negara khususnya Tiongkok dan juga untuk tetap menjaga stabilitas kondisi sebagai bentuk pelaksanaan dari Politik Luar Negeri Indonesia yang bebas aktif.

\section{Buku dan Artikel}

Arikunto, S. (1997). Prosedur Penelitian: Suatu Pendekatan Praktek. Edisi Revisi IV. Jakarta: PT Rineka Cipta.

Bitzinger, R (2016). China Militarisation of The South China Sea: Creating a Strategic Strait. RSIS Commentaries. Srirajaratnam School of International Studies

Bouchat, C. (2014) The Paracel Island and the US Interest and Approaches in the South China Sea. US Army War College.

Gunitskiy, V (2011). Encyclopedia of Power Security Dilemma. Sage Publication.

Hansen, B. (2019). Power Geopolitics in the Pacific Age East Asia, the United Nations, the United States and Micronesia at the edge of the 21st Century. Inkwater Press

Harvey, J (1997). Zone: Indonesia and the South China Sea. Asia Policy: Roundtable Non-Claimant Perspectives No 21, The National Bureau of Asian Research.

Shi, X (2015). UNCLOS and China's Claim in the South China Sea, Centre for Defence and Strategic 
Studies, Australian Defence College.

Stanlas, P (2010). The Spratly Dilemma External powers and Dispute Resolution Mechanisms. Amicus Europae.

Taffer, A. (2015). State Strategy in Territorial Conflict A Conceptual Analysis of China Strategy in South China Sea. Institute of Southeast Studies (ISEAS).

Zhao, X (2015). The Hidden Dragon: Explaining Chinese Aggressive Foreign Policy on the South China Sea Dispute. Indiana University.

Ziatek, A. (2017). The South China Sea Security Dilemma. International Relations Department Sklodowska University.

\section{Artikel}

Akbar, W (2017). Sebanyak 23 Gubernur Latihan Ala Militer di Natuna. Diakses dari https://www.cnnindonesia.com/na sional/20170519172148-20216025/sebanyak-23-gubernurlatihan-ala-militer-di-natuna.

Astungkoro, R. Satuan TNI Terintegrasi Berikan Daya Tangkal di Natuna. https://www.republika.co.id/berita /nasional/daerah/18/12/22/pk3zpy 430-satuan-tni-terintegrasiberikan-daya-tangkal-di-natuna.

Daud, A (2019). Luhut: Jokowi Akan Naikkan Anggaran Pertahanan Jadi 1,5\% dari PDB. Diakses dari https://katadata.co.id/berita/2019/ 03/31/luhut-jokowi-akan-naikkananggaran-pertahanan-jadi-15-daripdb.

Dony, B (2017). Gaya Para Gubernur Berpakaian Militer di Natuna. Diakses dari https://news.detik.com/berita/d3506133/gaya-para-gubernurberpakaian-militer-di-natuna.
Erricksson, A (2018). Shining a Spotlight: Revealing China's Maritime Militia to Deter its Use. Diakses dari https://nationalinterest.org/feature/ shining-spotlight-revealingchina\%E2\%80\%99s-maritimemilitia-deter-its-use-36842

Gumilang, P (2016). Kemhan Prioritaskan Anggaran untuk Pangkalan Militer Natuna. Diakses dari https://www.cnnindonesia.com/na sional/20160701164757-20142477/kemhan-prioritaskananggaran-untuk-pangkalanmiliter-natuna.

Indrawan (2015). Perkuat Militer di Natuna, Komisi I Setujui Alokasi Rp 450 Miliar. Diakses dari https://www.batamnews.co.id/beri ta-6927-perkuat-militer-di-natunakomisi-i-setujui-alokasi-rp-450miliar.html.

Haq, M (2017). China Protes Peta Baru Indonesia, Ini Kata Luhut. Diakses dari https://news.detik.com/berita/d3562657/china-protes-peta-baruindonesia-ini-kata-luhut

Ikhsan, M (2017). Pangkostrad: TNI Siapkan Skenario Tempur di Natuna. Diakses dari https://www.batamnews.co.id/beri ta-20350-pangkostrad-tnisiapkan-skenario-tempur-dinatuna.html

Lian, L (2018). NPC 2018: China Raises Military Budget by $8.1 \%$ in face of profound changes to national security environment. Diakses dari https://www.straitstimes.com/asia/ east-asia/china-raises-2018defence-spending-by-81-per-cent. Mangosing, F (2018). China's Fishing fleet a militia force. Diakses dari https://globalnation.inquirer.net/1 
71896/chinas-fishing-fleet-amilitia-force.

Malik, M (2013). History The Weak Link in Beijing Maritime Claims. Diakses dari https://thediplomat.com/2013/08/h istory-the-weak-link-in-beijingsmaritime-claims/.

McBeth, J (2019). Indonesia Arming Up in The South China Sea. Diakses dari https://www.asiatimes.com/2019/ 01/article/indonesia-arming-up-inthe-south-china-sea/

Nupus, H (2018). TNI resmikan satuan terintegrasi Natuna. Diakses dari https://www.aa.com.tr/id/headline -hari/tni-resmikan-satuanterintegrasi-natuna/1342718

Permana, P (2018). TNI resmikan Satuan Terintegrasi Natuna cegah ancaman perbatasan. Diakses dari https://www.aa.com.tr/id/headline -hari/tni-resmikan-satuanterintegrasi-natuna-cegahancaman-perbatasan/1342119.

Pletcher, K (2015). Spratly Island Reef, Shoals, Atolls, and Islets South China Sea. Diakses dari https://www.britannica.com/place/ Spratly-Islands.

Purnomo, N (2017). TNI Gelar Latihan PPRC di Natuna. Diakses dari https://www.tribunnews.com/nasi onal/2017/05/19/tni-gelar-latihanpprc-di-natuna

Putra, E (2015). Nasib Komando Gabungan Wilayah Pertahanan yang Dirancang SBY. Diakses dari

https://nasional.republika.co.id/be rita/nasional/umum/15/10/07/nvs weg334-nasib-komandogabungan-wilayah-pertahananyang-dirancang-sby.

Sarwanto, A (2016). Anggaran Terbatas, Pangkalan Militer Natuna Dibangun Bertahap.
Diakses dari https://www.cnnindonesia.com/na sional/20160622135305-20140110/anggaran-terbataspangkalan-militer-natunadibangun-bertahap

Sihendra (2016). Ulang Tahun TNI Yang Tak Biasa. Diakses dari https://tirto.id/ulang-tahun-tniyang-tak-biasa-bRcL

Sinaga, L (2017). Laut Natuna Utara dan Respon Tiongkok. Diakses dari

http://www.politik.lipi.go.id/kolo $\mathrm{m} /$ kolom-1/politikinternasional/1165-laut-natunautara-dan-respon-tiongkok.

Suastha, R (2017). Diprotes China, RI Daftarkan Nama Laut Natuna Utara ke PBB. Diakses dari https://www.cnnindonesia.com/int ernasional/20170720172204-106229239/diprotes-china-ridaftarkan-nama-laut-natuna-utarake-pbb.

Utama, A (2016). Jokowi Saksikan Skenario Tempur Sukhoi dan F16. Diakses dari https://www.cnnindonesia.com/na sional/20161006132642-20163705/jokowi-saksikanskenario-tempur-sukhoi-dan-f-16.

Valencia, M (2019). As US-China rivalry hots up, what does the future hold for Southeast Asian security and the South China Sea?. Diakses dari https://www.scmp.com/comment/ opinion/article/3027616/us-chinarivalry-hots-what-does-futurehold-southeast-asian.

Viray, P (2018). China Claims Natural Right put Troops Equipment on Spraly. Diakses dari https://www.philstar.com/headline s/2018/04/11/1804968/chinaclaims-natural-right-put-troopsequipment-spratlys 
Ziyadi, A (2016). Berikut Skenario Latihan Angkasa Yudha 2016 Di Natuna.

Diakses

dari http://militermeter.com/berikutskenario-latihan-angkasa-yudha2016-di-natuna/. 